\title{
Sri Lanka's Schmittian peace: Sovereignty, enmity and illiberal order
}

\author{
David G. Lewis
}

This is the pre-publication version. Please cite the published version:

David G. Lewis (2020), "Sri Lanka's Schmittian Peace: Sovereignty, Enmity and Illiberal Order", Conflict, Security and Development [DOI: $10.1080 / 14678802.2019 .1705067]$

\begin{abstract}
The dominant discourses and practices of post-Cold War liberal peacebuilding are increasingly challenged by illiberal and authoritarian alternatives. This article adds to the emerging literature on 'authoritarian conflict management' and 'illiberal peace' using the work of the controversial German jurist Carl Schmitt, the foremost theoretician of anti-liberal thought in the twentieth-century. I use the case of Sri Lanka to illustrate how Schmitt can be useful in understanding illiberal peace, not merely as an aberration from liberal norms of conflict resolution, but as an alternative paradigm that has an increasing global resonance beyond particular case studies. The Schmittian framework suggests that the most likely trend for postliberal peace is not towards an emancipatory model of hybridity and compromise, but a retrograde 'illiberal turn' towards authoritarian political order and highly illiberal practices.
\end{abstract}

Contact: David G. Lewis, Associate Professor of International Relations, Department of Politics, University of Exeter. Postal address: Department of Politics, University of Exeter, Exeter, UK, EX4 4RJ; email: d.lewis@exeter.ac.uk; Twitter: @david_g_lewis.

Bio: David G. Lewis is Associate Professor of International Relations at the University of Exeter. His research focuses on comparative authoritarianism and peace and conflict studies.

Acknowledgements: I presented an earlier version of this paper at a conference at the Bandaranaike Centre for International Studies (BCIS), Colombo, Sri Lanka, 29 June 2017. I would like to thank Rajesh Venugopal, Nicholas Farrelly, Claire Smith, and the other conference organisers for an invitation and funding to attend the conference. I would also like to thank Lars Waldorf and Gerard McCarthy for all their work in bringing this Special Issue to publication, and two anonymous reviewers for their comments and suggestions. 


\section{Introduction}

The dominant discourses and practices of post-Cold War liberal peacebuilding are increasingly challenged by illiberal and authoritarian alternatives. ${ }^{1}$ While post-Cold War 'liberal' peace-building attracted a remarkable array of theoretical and empirical literature, recent cases of what has been termed 'illiberal peace' or 'authoritarian conflict management' have lacked both detailed empirical investigations and persuasive theoretical and conceptual frameworks. ${ }^{2}$ A recent 'illiberal turn' in peace and conflict studies attempts to address this lacuna, including the articles in this Special Issue. In this contribution, I add to this emerging literature with an investigation of the ideational framework of 'illiberal peace', using the work of the controversial German jurist Carl Schmitt, the foremost theoretician of anti-liberal thought in the twentieth-century. I use the case of Sri Lanka to illustrate how Schmitt can be useful in understanding authoritarian responses to conflict. I argue that this type of 'authoritarian' or 'illiberal' peace is increasingly prevalent in responses to $21^{\text {st }}$ century conflicts and poses a profound challenge to more liberal concepts of conflict resolution that became widespread after the end of the Cold War.

The 2002-2006 Sri Lankan peace process, which allowed Sri Lanka to experience four years of fragile peace, was an archetype of liberal peace-building. The essential norms and principles of liberal peacebuilding, first widely articulated in the 1992 UN Agenda for Peace, were all evident in the Sri Lankan case. First, intractable civil wars could not be easily solved by the participants themselves without intervention by external actors. In Sri Lanka, this role was played by Norway, accompanied by an international monitoring mission, and an extensive network of international NGOs, government agencies and international organisations. ${ }^{3}$ Second, liberal peace rejected purely military solutions to conflicts, instead promoting negotiations among all the parties to the conflict on an even footing; intensive peace talks with the Liberation Tigers of Tamil Eelam (LTTE) were held in Sri Lanka in 2002-03.

Third, peace-building was based on a premise that armed conflicts had 'root causes' - well-founded grievances articulated by defined social groups - that needed to be addressed to ensure sustainable resolution of conflicts. In the Sri Lankan case, this involved finding ways to address claims of political and economic exclusion by Tamil communities. And fourth, liberal peace-building claimed that the state - particularly in an authoritarian political system - was often the primary cause of conflict. Consequently, lasting peace would also require political and economic liberalisation, and a sustainable peace would require the active involvement of civil society.

After 2006 the Sri Lankan government rejected all these liberal principles as the peace process degenerated into a brutal counterinsurgency that resulted in the defeat of the Liberation Tigers of Tamil Eelam (LTTE) in 2009 and the end of a 30-year civil war. ${ }^{4}$ 
The ideal type of liberal peace-building was only ever partially implemented, but elements of the framework were evident in most international responses to conflict after the Cold War. Even before the Sri Lankan peace process, it was clear that the results of liberal peacebuilding were often disappointing. After international peace processes, countries often broke down into renewed conflict, and few emerged as sustainable democracies. ${ }^{5}$ Even advocates of 'liberal peace' sought to reform post-conflict interventions to bring the state back in and to emphasise the need for political order. ${ }^{6}$ By the 2010s there was evidence that more governments were seeking military victories to end civil wars rather than through peace settlements. ${ }^{7}$ Civil wars took place in a changing international normative landscape, marked both by the legacy of the US-led Global War on Terror and the resurgence of Russia and China, which increasingly acted to limit the rise of liberal norms and practices in the international system. ${ }^{8}$ At the UN World Summit in 2005, all states unanimously signed up to emerging ideas of how to respond to internal conflicts, such as the Responsibility to Protect (R2P), but over the subsequent decade these and other liberal norms came under increasing attack. ${ }^{9}$ Russia and China repeatedly intervened in the Security Council to block attempts by Western states to address internal conflicts and mass human rights violations under the rubric of threats to international peace. In doing so, they slowly reshaped many peace-building norms, reflecting a broader ideological backlash against post-Cold War liberalism.

This crisis in the liberal order was accompanied by a crisis in the academy over how to conceptualise and understand these shifting responses to conflict. Proponents of liberal peace set about 'saving' it from its critics, while failing to recognise a much more profound shift in international relations that was driving normative contestation. ${ }^{10}$ Critics of liberal peace tended to overlook 'hard' cases of illiberal peace, which were obscured from view by a critique of global liberal order that valorised forms of local resistance, but left little space for the agency of non-liberal powers. ${ }^{11}$ While some scholars argued that a post-liberal peace might be a potentially emancipatory paradigm that encouraged hybrid forms of peace, formed through the dynamic interplay of the 'liberal' and the 'local', in reality the shift away from liberal peace-building has been a retrograde 'illiberal turn' towards authoritarian political order and illiberal forms of practice. A new wave of literature has explored these illiberal responses to conflict in a range of cases. ${ }^{12}$

These explorations of 'illiberal peace-building' ${ }^{13}$ or 'authoritarian conflict management ${ }^{14}$ have yet to explore the ideological elements of this turn. Yet there are common ideational premises on which illiberal responses to internal conflict have been built, which reflect their place within a much wider political and ideational context. In Sri Lanka the rise of President Mahinda Rajapaksa and the turn to war in Sri Lanka can be located within a much wider contemporary reaction against international liberal norms, an anti-liberalism accurately characterised elsewhere as a 'new conservatism'. ${ }^{15}$ This radical conservatism promoted an anti-pluralist and hierarchical politics characterised by 
the search for political order through centralised, sovereign power within a homogeneous political community, and the demarcation of hard boundaries between communities, defined by enmity and otherness. It viewed liberalism as an ideology that promoted destabilising political change and which undermined the values and boundaries that conservatives claim are fundamental to group identity. The most articulate theoretician of such a radical conservative ideology was the controversial German jurist and political theorist, Carl Schmitt (1888-1985). ${ }^{16}$ Despite Schmitt's morally tainted biography as a member of the Nazi party, his ideas have been deployed both on the left and right of contemporary politics as a powerful polemic against liberalism. ${ }^{17}$ Using Schmitt as a theoretical framework to understand the illiberal turn in conflict management helps us to locate the Sri Lankan war and other case-studies within a broader ideological and political context.

Three of Schmitt's major ideas about conflict and political order are particularly relevant in an analysis of Sri Lanka's 'illiberal peace'. First, Schmitt argues that any pluralist political order is destabilising and conflict-producing. Sustainable political order requires a centralised, sovereign power, which can act decisively against existential threats to the nation, if necessary by acting outside the law. Schmitt's famous declaration - 'Sovereign is he who decides on the exception' 18 - summarises his argument that sovereignty is defined by the capacity of a single decision-maker to act outside constitutional norms in response to a crisis that threatens the very existence of the state. A political leader constrained by constitutional principles or international norms is not fully sovereign and cannot effectively protect the state in the exceptional situation.

Second, Schmitt denies that conflict can be overcome, 'resolved' through a process of dialogue and consensus, as proposed by liberals. Such efforts, he claims, are merely attempts to avoid political and social reality. A refusal to identify the enemy does not negate the reality of conflict. Schmitt writes that it would be a deranged calculation to suppose that the enemy could perhaps be touched by the absence of a resistance'. ${ }^{19}$ Instead, a people must identify the enemy, both to ensure its own survival and to define its own identity as a political community. The political, for Schmitt, is ultimately about defining this 'distinction ... between friend and enemy'. ${ }^{20}$ This understanding of politics as the identification of enmity easily segues into war, blurring the line between political and military conflict: 'to the enemy concept belongs the ever present possibility of combat', argues Schmitt. ${ }^{21}$ The concepts of 'friend' and 'enemy' - and therefore the very idea of politics - 'receive their real meaning precisely because they refer to the real possibility of physical killings'. ${ }^{22}$

Third, Schmitt argues for a highly political - and anti-liberal understanding of space. ${ }^{23}$ For Schmitt, ideas and space are intimately linked; law and politics are rooted in the land. ${ }^{24}$ Liberalism, on the other hand, promotes a destabilising 'spacelessness', through which it asserts universal norms, which are detached from any grounding in space. Schmitt rejects any concept of 'spaceless political ideas', ${ }^{25}$ such 
as universal ideas of human rights, instead asserting an understanding of law as located in place, generating particularistic ideas and beliefs. There are no 'spaces without ideas or principles of space without ideas' ${ }^{26}$ Political control of land underwrites not only the identity of a sustainable political community, but also law, which emerges from local culture, politics and social reality, not abstract principles and norms that are disconnected from particular spaces. 'All law', writes Schmitt, "is "situational law"". ${ }^{27}$ Legal thought must be expressed in accordance with 'a historical, concrete, total order; any assertion of a 'free-floating' jurisprudence, with 'free-floating rules', is symptomatic of 'a disintegrated order'. ${ }^{28}$

\section{Political sovereignty}

Models of illiberal peace can be found under diverse political systems, including those characterised as 'hybrid' or 'democratic': Lewis et al. mention China, Israel, Russia, Sri Lanka, Ethiopia and Turkey as possible examples, while Smith studies 'illiberal peace-building' in Indonesia. ${ }^{29}$ This difficulty of mapping political regime type against patterns of peace-building practice has led some scholars to focus on authoritarian practices, rather than regimes. ${ }^{30}$ Such an approach is useful in extending the scope of analysis beyond a simplistic democratic/authoritarian binary, but it has the tendency to downplay the importance of centralised concentrations of power, instead disaggregating the state into competing institutions, decision-making agencies and de-centred practices. Such an approach underestimates the ideational drive in contemporary conservative politics to re-centre power, not only in institutional terms, but in the person of a particular type of political leader.

This drive towards personalistic, authoritarian modes of politics corresponds to the Schmittian concept of sovereignty, understood as a 'monopoly of decision-making', the ability of a political leader to take decisions in the face of an existential threat, even decisions that violate the law or constitution. Sovereignty, argues Schmitt, should not be defined as 'the monopoly to coerce or to rule, but as the monopoly to decide' 31 The pursuit of sovereignty as a monopoly of decisionmaking requires a political system that removes decision-making from other actors, by opposing the influence of international agencies and foreign governments, undermining the autonomy of domestic state institutions, and severely curtailing the independence of the courts and justice system. The Schmittian sovereign rejects constraints imposed by international law, or by domestic constitutional provisions. True sovereignty lies in the ability to break the rules, to declare the exceptional case.

Within Sri Lanka's democratic system, Mahinda Rajapaksa attempted to construct just such a Schmittian sovereign order, creating a monopoly of decision-making within his own small family-based network, and side-lining alternative state institutions and judicial constraints. A powerful executive presidency in Sri Lanka dates back 
to the 1978 Constitution, and its first incumbent, President Jayewardene (1977-88), also gained extensive semi-authoritarian powers. But arguably no leader had gathered as much power as Rajapaksa. After winning election as president in November 2005, Rajapaksa appointed his brother Gotabaya Rajapaksa as defence secretary, followed by other family appointments. He quickly took control of parliament, persuading opposition deputies to cross the floor to join his Sri Lanka Freedom Party (SLFP)-led government by offering ministerial positions. By 2013 Sri Lanka had the largest government in the world, comprising more than 100 ministers and deputy ministers, managed through an extensive and hierarchical system of patronage and clientelism. In September 2010 parliament passed the 18th amendment to the constitution, which ended presidential term limits and placed the independent judicial appointments body and other oversight commissions under direct presidential control. In January 2013, at Rajapaksa's insistence, parliament impeached an independent-minded Chief Justice, completing what was later termed a 'constitutional coup'. ${ }^{32}$ At times it seemed possible that Rajapaksa would eclipse Sri Lanka's democratic forms; his supporters claimed he was reviving the history of Sri Lankan kings, above all the ancient, semi-mythical King Dutugemunu, who - in nationalist historiography - defeated a Tamil king and united the island. ${ }^{33}$

Under Article 155 of the Constitution the president is able to declare a state of emergency and gain almost unconstrained powers. ${ }^{34}$ The government first declared a state of emergency in 1958, and Sri Lanka has been under emergency rule for most of its modern history. These emergency regulations - together with the Prevention of Terrorism Act (PTA) - allow extensive limitations on fundamental rights, and contradict international standards, notably the International Covenant on Civil and Political Rights (ICCPR). ${ }^{35}$ Yet, in Schmitt's argument, even the constitutional provision of emergency powers continues to impose undue constraint on a sovereign leader. Schmitt introduces an important distinction, between a 'commissary dictatorship', which suspends the law or the constitution for a defined period of time to protect the existing constitutional order, and a Schmittian sovereign who is unrestricted by constitutional constraints or temporal limits, but is located both within and without the constitutional and juridical order. ${ }^{36}$ Therefore the Schmittian exception goes beyond the already broad powers of emergency rule to develop a pattern of practices that violate legal and constitutional norms, and a series of spaces where an exceptional form of order, distinct from that in the rest of the state, is maintained.

From the very beginning of the Rajapaksa presidency, there were reports of incidents even beyond the scope of the PTA, including disappearances of activists, journalists and political opponents, often dubbed 'White Van' disappearances. According to a subsequent UN investigation: 
White vans were used to abduct and often disappear critics of the Government or those suspected of links with the LTTE, and, more generally, to instil fear in the population. ... Those abducted were removed to secret locations, interrogated and tortured in a variety of ways, including through beatings, forced nudity, suffocation with plastic bags, partial drowning, extraction of finger or toenails, or administering electric shocks. Many were killed and their bodies disposed of secretly. ${ }^{37}$

This pattern of extra-judicial attacks did not cease with the end of conflict. Throughout the Rajapaksa presidency, human rights defenders detailed extra-judicial killings, physical attacks, massacres, rape and other forms of violence by state or para-state bodies outside the law. ${ }^{38}$

Exceptionality also takes on geographic form, constructing a spatiality that is often widely understood in society, but not necessarily codified in law. In these spaces law is either formally suspended or the exceptional nature of the counterinsurgency effectively constitutes a state of exception, even in the absence of the declaration of martial law. ${ }^{39}$ In such exceptional spaces, the law and the constitution may be violated, but these are not merely spaces of random violence or chaos. Giorgio Agamben argued that the exception is a 'space without law' characterised only by 'anomie', and 'a pure violence without logos'. ${ }^{40}$ But, as Schmitt argued, in the exception 'the state remains, whereas law recedes'. The exception is not a situation of anarchy: rather, 'order in the juristic sense still prevails even if it is not of the ordinary kind'. ${ }^{41}$

During and after the conflict, the north and east of Sri Lanka constituted - in varying degrees - spaces of exception, where normal rules and laws were effectively suspended, but informal order was maintained with a clear chain of command presiding over extraconstitutional actions, including by state and formally non-state actors, such as paramilitary groups. In its ultimate, most extreme form, the exceptional space was demarcated during the final months of the Sri Lankan conflict in 2009, in 'No Fire Zones' or 'Safe Zones' in which government commitments to avoid civilian casualties were repeatedly violated. ${ }^{42}$ The third, final 'No Fire Zone' was declared in a narrow strip of land near Mullaitivu, but government forces continued to attack the area. The LTTE's willingness to kill civilians attempting to leave the zone produced a double state of exception, in which tens of thousands of civilians died. Subsequent investigations claimed that this space saw 'some of the most intense shelling and fighting of the entire conflict', resulting in 'immense devastation and civilian suffering, ${ }^{43}$ and scenes 'reminiscent of hell'. ${ }^{44}$

The exception emerges not only in concrete spaces, but also in attempts by the regime to control the flows of resources across borders and spaces. The importance of political economy is often underestimated in discussions of conflict management and postconflict order. ${ }^{45}$ In the context of a globalized economy, a sovereign power seeks to impose formal and informal controls over resources, both through legal and extra-legal means. As the Sri Lankan conflict 
intensified in 2005-06, the LTTE launched a major fundraising effort among diaspora communities, threatening individuals and businesses who refused to pay informal taxes. ${ }^{46}$ The government was often able to disrupt such flows legally, partly by the use of new measures against terrorism financing, introduced internationally in response to the threat from Al-Qaeda. Inside Sri Lanka, the LTTE had extended its informal system of taxation during the 2002-05 ceasefire to include some nominally government-controlled areas and Muslim communities in the north and east. ${ }^{47}$ In these areas, the government used exceptional measures to interdict LTTE funding, including permitting progovernment Tamil paramilitaries to take over control of LTTE taxation of Tamil communities. In Eastern Province, these taxation networks reportedly came to be controlled by the breakaway Tamil TMVP paramilitary group led by Vinayagamoorthy Muralitharan, more commonly known as Colonel Karuna, who broke with the LTTE in 2004. In Jaffna another pro-government militia, the EPDP, was also accused of extortion rackets and criminal activities. ${ }^{48}$

Such exceptional practices pervade post-conflict economies through informal institutions that are often labelled 'corruption', but more accurately comprise hierarchical patron-client networks, which often have a powerful influence on the success or failure of political settlements and peace agreements. ${ }^{49}$ Patronage networks and informal economic transactions play a particularly important role in illiberal peace settlements, enabling regimes to buy off opponents and regulate access to rent-seeking institutions to reduce the propensity of armed actors to resume violence. ${ }^{50}$ Extensive patronage networks in the economy can contribute to the construction of Schmittian forms of sovereignty, because they enable political leaders to extend a culture of exceptionality and informal control into all areas of finance and the economy. High-level corruption was not a new phenomenon in Sri Lanka - public sector corruption had plagued politics under governments run by different parties. After the war, however, reports suggest that informal economic dynamics began to take on a different structure, producing a more centralised, vertical patronage network. Through their control of government ministries, the Rajapaksa family reportedly controlled some 80 per cent of budgetary spending, and their influence was alleged to extend to many sectors of the economy, including deals with international investors, notably a significant Chinese investment in Hambantota port. ${ }^{51}$ Several criminal investigations were launched into allegations of corruption under the Rajapaksa government, although family members strenuously denied any wrong-doing. ${ }^{52}$ Corruption charges against Gotabaya Rajapaksa were dropped in November 2019, after he won the presidential election. $^{53}$

\section{Defining the political}

The second element of anti-pluralistic order in Rajapaksa's Sri Lanka was the attempt to construct a new understanding of a Sri Lankan political community through the constant articulation of distinctions 
between 'them' and 'us', between 'friend' and 'enemy'. Schmitt argues that a political community is defined by its demarcation from other peoples and nations, through the identification and declaration of its existential enemy. It is this defining antagonism that Schmitt terms 'the political', the foundational dynamic, in his thinking, of all social and political life. In Schmitt's famous formulation - 'the concept of the state presupposes the concept of the political ${ }^{54}$ - the political community exists prior to the state, formed by a collective agreement to identify the community's enemy. Sustainable political order requires the political community to be clearly demarcated from others by frontiers, boundaries and walls, and not divided internally by federalism, autonomy or other pluralistic political forms. Schmitt's conceptualisation of 'the political' certainly produces 'pluralist consequences', but only in relations between states, and 'not in the sense that, within one and the same political entity, instead of the decisive friend-and-enemy grouping, a pluralism could take its place without destroying the entity and the political itself ${ }^{55}$ Schmitt rejects pluralism within the state in favour of a homogeneous political community, in which there is collective agreement on the identification of the enemy.

The Rajapaksa regime sought to shape a new, non-pluralist understanding of Sri Lankan society, a Schmittian political community defined by demarcation from its enemies. The Sri Lankan peace process had been based on an assumption that difference and pluralism could be institutionalised in forms that would produce lasting peace. The Sinhala nationalist response was to reject any pluralist conceptualisation of the nation and reject the claim that collective grievances among Tamils in relation to the Sri Lankan state were so great that they required either Tamil autonomy or a separate state. The government denied that the enmity line in Sri Lanka was between different ethnic communities, but rather identified it as running between the wider political community and a terrorist group, which had no legitimate claim to represent any part of the community. President Rajapaksa repeatedly denied that there was an ethnic conflict in Sri Lanka, instead asserting that 'Sri Lanka's security forces are fighting a terrorist group, not a particular community'. ${ }^{56}$ The government sought to identify the LTTE as the existential public enemy, claiming that it lacked any legitimacy as a potential negotiating partner or as a genuine representative of the Tamil community.

This delegitimization of the LTTE was bolstered by a discourse that denied that the Tamil community had any legitimate grievances - over political representation, language laws, discrimination or state violence. By denying the validity of popular grievances, the government could claim that the main driver of conflict was the availability of economic, political and spatial resources to the LTTE, in line with the theories of Fearon and Laitin, and Collier et al., who rejected claims that rebellions were driven by collective grievances, and rather focused on 'opportunity' as a driver of conflict. ${ }^{57}$ The denial that the Tamil community had any genuine collective grievances as an ethnic group, or that the LTTE was a legitimate party to articulate such 
grievances, enabled the declaration of the LTTE as the public enemy of all Sri Lankans. In this discourse, the people of Sri Lanka, regardless of ethnicity, were the collective victims of a terrorist group, which exists outside the boundaries of the political community. President Rajapaksa emphasised this understanding of unity in his Victory Day address on 26 May 2011, celebrating 'the victory of ensuring the right of every citizen of the country to live in harmony'. He argued that 'our troops [...] did not target any communities or religions, and did not march ahead with hatred towards anyone.... Today we do not hear a single incident of communal disharmony in this country. Two years ago, we celebrated the victory over terrorism without hurting the feelings of any community'.

Yet the construction of this political community as an apparently inclusive group opposed to a terrorist organisation repeatedly foundered because this all-embracing vision was not one of an inclusive civic nationalism, but was ultimately grounded in a Sinhala nationalist discourse. In speeches, President Rajapaksa continually constructed a collective 'we' that was apparently inclusive of all Sri Lankan citizens, yet was still reliant on familiar tropes and images from Sinhala-Buddhist nationalist discourses, and accompanied by practices that drew very different lines of enmity within society. This collective 'we' - both all-embracing and yet Sinhala-Buddhist at core - was further legitimised as a majority forged through democratic processes. As Jonathan Spencer has argued, Sri Lanka's ethnocratic politics have always been intertwined with democratic mechanisms. ${ }^{58}$ Democracy can act as a conflict-reinforcement mechanism, in which society is divided by "the moment when "the people" in whose name a modern democracy acts, define themselves in opposition to some other kind of "people". 59 Sinhala radicalism was often augmented by other social and economic concerns in constructing an electoral majority - for example, Rajesh Venugopal has demonstrated how Sinhala nationalist voices were also amplified by opposition to neoliberal reforms introduced by the United National Party (UNP) government in 2002-03. ${ }^{60}$

In this way, Sinhala nationalism deployed democracy as part of a wider strategy of legitimation - by invoking democratic norms it could also promote majoritarian solutions to the conflict. ${ }^{61}$ As Qadri Ismail writes, the Sinhalese Buddhist majority narrative argues that the people deserve

to enjoy the universally recognised rights and privileges of a majority; all it has done since independence is exercise this privilege within a democratic framework - this privilege of a majority that is not just democratic but democracy. ${ }^{62}$

In this way, majoritarian concerns become identified with the democratic process itself, and begin to negate the possibility of minority concerns and protections.

Schmitt offers a similar understanding of democracy, which views liberal democracy as an oxymoron, and instead seeks to divorce 
democracy from the rule of law and the parliamentary process. He argues instead for an illiberal form of democracy, claiming that 'democracy is correctly defined as the identity of governed and governing', ${ }^{63}$ To produce such a coalesced identity, democracy requires a sense of homogeneity, beyond simply being members of a single political unit defined by legal citizenship. ${ }^{64}$ Although homogeneity may often be defined by ethnicity, for Schmitt 'what is important ... is not the nature of the similarity on which homogeneity is based', but the possibility of demarcating clear boundaries of a community. ${ }^{65}$ By defining the enemy, a new understanding of the political community can be formed, based not primarily on ethnicity, culture or religion but on a simple antithesis of friend-enemy. This united homogeneous community may still include many social groups and ethnicities, but it denies a recognised status for minorities as selfdefining, legally protected social groups inside the community. In a speech in 2009 Rajapaksa argued:

We have removed the word minorities from our vocabulary three years ago. No longer are there Tamils, Muslims, Burghers, Malays and any other minorities. There are only two peoples in this country. One is the people that love this country. The other comprises the small groups that have no love for the land of their birth. Those who do not love the country are now a lesser group. $^{66}$

A clear distinction between 'those who love this country' and 'those who do not' becomes the fulcrum around which an enemy discourse revolves. While the immediate enemy is portrayed as the LTTE initially distinguished from the wider Tamil community - the discursive framing always permits the widening of this identification to include a much wider spectrum of possible enemies, both contemporary and historical, internal and external. Molly Wallace notes that Rajapaksa's discourse represents the LTTE as the latest in a series of 'invasions', historical incursions into the body politic by ancient Tamil rulers or more recent colonial intrusions. ${ }^{67}$ The notion of an embattled Sinhalese nation, threatened by Tamil groups inhabiting a broad space across South Asia and northern Sri Lanka, has been a central element in Sinhala nationalist myths. ${ }^{68}$ In a speech to parliament in 2009, Rajapaksa used history to explain 'how it was possible to obtain the proud victory we have achieved today by defeating the world's most ruthless terrorist organization'. He linked the victory against the LTTE with victories over historical, external enemies, creating a discourse that defines Sri Lanka as a nation historically constituted by these conflicts with external enemies:

We are a country with a long history where we saw the reign of 182 kings who rule [d] with pride and honour for ... more than 2,500 years. This is a country where kings such as Dutugemunu, Valagamba, Dhatusena and Vijayabahu defeated enemy invasions and ensured our freedom. As much as Mother Lanka 
fought against invaders such as Datiya, Pitiya, Palayamara, Siva and Elara in the past, we have the experience of having fought the Portuguese, Dutch and British who established empires in the world. ${ }^{69}$

This reference to historical cases emphasises the 'external' nature of the enemy, which is always outside the legitimate community, and represents an existential threat to it. The discursive linkages are clear: between the Tamil 'invasions' of the past, the colonial invasions of the $16^{\text {th }}-19^{\text {th }}$ centuries and the - unspoken but implicit - connection between contemporary international organisations - the 'West' - and modern Tamil militancy. In this discourse, the external enemy - the Norwegian negotiatiors, the UN, Western politicians, international NGOs - are all ultimately bound up with the internal threat from Tamil separatists to the Sinhala unitary state and its Buddhist identity.

A Schmittian discourse that constructs the nation by reference to its enemies inevitably also identifies internal enemies, or 'fifth columns', which are presumed to be aiding and abetting the external enemy. Such a discourse is even deployed by historians in reference to the actions of historical Tamil communities in ancient times. ${ }^{70}$ In post-war Sri Lanka, NGOs, human rights groups and international organisations were portrayed in ways that defined them as internal enemies, sympathetic to terrorism, outside the body politic, and therefore even outside the nation. NGOs and other 'neutral' actors, which had supported the peace process, were labelled as 'traitors', and many activists were targeted under the wide-ranging Prevention of Terrorism Act (PTA). There were frequent violent attacks on newspaper offices and on journalists themselves. Foreign journalists were sometimes banned, or barred from covering the north of the country. ${ }^{71}$ Humanitarian agencies - often a source of critical information in war - were also carefully controlled and, in some cases, manipulated. ${ }^{72}$ Non-governmental organisations that espoused a compromise solution to the conflict were often labelled as 'LTTE sympathisers', and 'peace' itself became a suspect word. ${ }^{73}$ In short, the regime 'controlled societal discourse through terror, intimidation of the media and targeted killings, leaving the state-sponsored media as the dominant source of information'. ${ }^{74}$

Proponents of 'agonistic peace-building', which builds on the work of Chantal Mouffe, agree with Schmitt that liberal ideas too easily suppress antagonisms and seek a false, depoliticized consensus that is ultimately destabilising. ${ }^{75}$ Instead, they argue for a 'dissensus' that recognises and embraces discord, and acknowledges non-liberal voices as valid participants in the political sphere. The ultimate goal is that 'in accepting these non-liberal politics, new possibilities, such as emancipation, could be imagined and worked toward'. ${ }^{76}$ This argument offers a corrective to the sometimes artificial and superficial consensus that often accompanies liberal peace-building initiatives. The Norwegian-led peace process in Sri Lanka too easily overlooked dissident voices. ${ }^{77}$ Yet the agonistic reading, which attempts to claim an alternative reading of Schmitt as an ally towards an emancipatory 
peace, struggles to explain how a politics of agonism can be distinguished from a politics of antagonism, except through the mediating operations of liberal institutions, such as the rule of law and parliamentary democracy. Paradoxically, agonistic peace-building ignores Schmitt's most cogent critique of pluralism, which warns that the tolerance of illiberal parties within a democratic system leaves the state vulnerable, because 'the institutions and concepts of liberalism, on which the positivist law state rested, became weapons and power positions in the hands of the most illiberal forces', threatening the 'destruction of the state'. ${ }^{78}$ Moreover, by accepting all-comers within a framework that recognises and celebrates discord, agonistic peacebuilding risks reiterating a familiar critique of Schmitt, most clearly articulated by Hannah Arendt, who accused Schmitt of creating 'formal-technical' generalisations, within which 'any content becomes acceptable'. ${ }^{79}$ By building on Schmitt's definition of the political as the distinction between friend and enemy, agonistic theories risk reifying the very differences that fuel a politics of antagonism and conflict. As Spencer concludes, an attempt to deploy 'an eviscerated Schmitt', tamed through the work of Chantal Mouffe into support for an agonistic democracy, too easily glosses over the 'disturbing political implications' of Schmitt's thought. ${ }^{80}$

As Schmitt knew only too well from 1930s Germany, the enemy discourse - far from embedding a sustainable sense of self - can have profoundly dangerous and destructive outcomes both in relation to minorities and society as a whole. Its deployment in politics mobilises majority communities in ways that become embedded and selfreproducing, not in relation to one specific objectivised enemy, but as a continuing dynamic of political hatred. This reproduction of enmity lines through alternative targets was evident in the post-war vilification of Sri Lanka's Muslim communities by militant Buddhist groups. According to the International Crisis Group, the government gave 'tacit - at times explicit - support for militant Buddhist attacks on mosques, as well as Muslim businesses and cultural practices' ${ }^{81}$ Buddhist radical groups, such as the Bodu Bala Sena (Buddhist Power Force, BBS), fuelled inter-racial tension using social media and mass rallies to propagate claims about the perceived threat posed by Muslim communities to the Sinhala nation. ${ }^{82}$ As Klem notes, 'BBS shifted the thrust of Sinhala nationalism towards the Muslims' in a 'rearticulation of Sri Lanka's ethno-nationalist conflict'. This was 'neither a derivate of Sinhala-Tamil antagonism, nor completely separate from it'. ${ }^{83}$ Rather, the anti-Muslim violence emerged from within the framework of an already embedded friend-enemy discourse that denied pluralism and advocated homogeneous and fixed identities as the basis of politics, even if the referents of this discourse evolved over time. At one anti-Muslim rally, leaders railed against 'pluralist' values, claiming 'this is a Sinhala country, Sinhala Government. Democratic and pluralistic values are killing the Sinhala race. ${ }^{84}$ After a two-year lull under the new administration after 2015, violence broke out again in 2017-2018, in a series of attacks by militant Buddhist groups on Muslim homes and businesses, forcing the government to introduce a 
state of emergency. Inter-communal tensions were further heightened following terrorist attacks in April 2019, claimed by the Islamic State militant group, which killed more than 250 people.

\section{Spatial politics}

Liberal responses to conflict often attempt to resolve, blur and efface spatial distinctions, through the promotion of cross-border trade and mobility, and by supporting complex political settlements involving varying degrees of self-rule, such as federalism, autonomy and decentralisation. On rare occasions, peace settlements may advocate the separation of conflict regions into new states, as occurred in East Timor, Kosovo and South Sudan. Even these territories are heavily internationalised in liberal thinking. New territorial boundaries are entangled with places outside the state - places of diplomatic practice in Geneva or New York, global financial spaces, or the spaces occupied by diasporas. During peace processes, negotiators seek ways of removing actors from contested, concrete spaces to alternative locations 'outside space', where dialogue and conflict resolution might be more feasible. In the Sri Lankan peace process, Norwegian negotiators presided over formal talks in such 'spaceless places': luxury hotels in Thailand in September and October 2002; Oslo in December 2002; Nakorn Pathom (Thailand) in January 2003; Berlin in February 2003; and Hakone (Japan) in March 2003. ${ }^{85}$

An alternative authoritarian conceptualisation of order seeks to reassert boundaries and articulate a singular conceptualisation of space. Carl Schmitt's authoritarian political theory 'attempts to form order based on resolution, exception, restoration of space, and the creation of borders' ${ }^{86}$ In Sri Lanka the conflict was often represented as a binary clash of incompatible spatial projects, between a Sinhalacentric unitary state and the proposed state of Tamil Eelam. This binary conflict was complicated by the distinction between liberal effacement of space and the attempts by both sides in the conflict to assert a bounded sense of territory, occupied by an autochthonous, homogeneous people. Each side argued for an authentic, original historical relationship to the land that legitimised their political order.

The centralised vision of a unitary state in Sinhala nationalist thought is largely a modern phenomenon, brought into being both through the practices of colonial governance and through the Sinhala nationalist reaction to colonial rule, in which a Buddhist Sinhala revivalism claimed a unitary sacral and political space. ${ }^{87}$ After the 1950s this spatial imaginary became a central trope in Sinhala Buddhist politics, enabling political leaders to oppose any substantive devolution of power by claiming such policies as inherently destructive of Buddhist interests on the island'. ${ }^{88}$ In the pre-modern period, however, Sri Lanka had operated through a 'fuzzy' logic, 'in which the concept of identities, political rule, borders and statehood was highly syncretic, inclusive, fluid, relational and context-bound' ${ }^{89}$ In sharp contrast to contemporary Buddhist nationalist thought, Wijeyeratne refers to an historical tradition of 'Buddhist cosmic 
disorder' in pre-colonial Sri Lanka, which was 'incorporative of diversity and essentially non-hierarchical in administrative form' ${ }^{90}$

This fluid, non-hierarchical logic was very different from Schmitt's exclusionary, homogeneous understanding of space, in which 'the solid ground of the earth is delineated by fences, enclosures, boundaries, walls, houses, and other constructs'. ${ }^{91}$ In Schmitt's account, this close relationship to a bounded land is in itself a form of resistance against a totalising global liberalism. Schmitt conjures the figure of the 'telluric' partisan, who 'defends a piece of land with which he has an autochthonous relation' 92 in a struggle to assert a local sense of space against a liberal order. This claim recalls a particular Sinhala vision of society, which claims the 'peasantry' as the 'historical and moral core of Sinhalese (as opposed to Sri Lankan) society'. ${ }^{93}$ The Sinhala rural population, embedded on the land, is the core of the Sinhala nation, but is constantly threatened by externallyoriented mobilities, whether in the form of colonialism, imported labour on plantations, or - in more recent times - the mobility of labour migration outside Sri Lanka. According to Rampton, this 'sons of the soil' trope "established a key frontier of "authenticity" between the autochthonous on the one hand and the foreign, marginal and threatening on the other' ${ }^{94}$ While such a frontier is ever-present in Sinhala nationalism, the elements posited as outside the authentic national space have fluctuated to include: 'British colonial power, Muslim and Tamil minority groups, Christians, India, NGOs, anglicised elites, and most recently Western donor states including particularly Norway'. ${ }^{95}$ The exact identity of the external object is less important than the constant re-articulation of the frontier, which 'remains a key element in fuelling a nationalist desire for the recovery of an autarkic sovereignty, a desire that is frequently articulated as the reinvigoration of the lost glory of Buddhist kingdoms; of the ancient past through the reunification of the island as a Sinhala Buddhist state and society'. ${ }^{96}$

Tamil nationalism also asserted clear boundaries and exclusionary spaces in territory that had not been clearly delineated along ethnic lines historically. Although historical references to the Kingdom of Jaffna are frequently invoked, the modern claim for a territorially defined Tamil homeland gained traction in a mutually reinforcing dynamic with anti-Tamil violence from the late 1950s onwards. ${ }^{97}$ The spatial politics of the LTTE were highly exclusionary, not only against Sinhalese communities but also in acts of ethnic cleansing against Tamil-speaking Muslim communities. Rebel groups use space not only as a form of economic and demographic resource or a space to organise and retrench, ${ }^{98}$ but also to construct what Brenner calls 'insurgent social orders'. ${ }^{99}$ Even non-democratic rebel groups seek to develop legitimacy in such spaces: the LTTE sought legitimacy with the majority Tamil community, by evoking nationalism and tradition, through the practices of custom and ritual, and through charismatic leadership. ${ }^{100}$ The proto-state developed by the LTTE during the civil war demonstrated how a rebel movement can control and shape space not only as a resource for armed rebellion, but as a mechanism to 
construct a socio-political order, with a particular symbolic and normative content. Just as Sinhala nationalists sought legitimacy by envisioning a homogeneous island-wide space, inspired by nationality myths, so the LTTE used 'symbolic languages of authority' 101 to assert a similarly exclusionary social and political order within their own claimed territory.

With the defeat of the LTTE, this rebel spatial order was carefully dismantled and fragmented, not only through military encampment and patrols by the Sri Lankan army, but also through the destruction of collective memories, represented by LTTE cemeteries and monuments, often replacing them with Sri Lankan military encampments and Sinhala memorialisation. ${ }^{102}$ Infrastructure and transport projects aimed to reterritorialize the island as a unitary space. The development project Uthuru Mithuru (Northern Friendship), which aimed to reconnect the rail link between Colombo and Jaffna (closed in 1990 after numerous bomb attacks by the LTTE), mounted an emotive propaganda campaign, with the objective 'to reengage northerners in a broader discourse of sovereignty evidenced through state-led reconstruction efforts' ${ }^{103}$ Yet, like the official discourse of a united political community, the sovereignty discourse also veiled a militarised, nationalist sentiment in post-conflict reconstruction. The Sri Lankan armed forces were actively involved in reshaping the geography of the north: they took on new roles in economic and infrastructure development, including reconstruction projects, business development and seizing tracts of land for economic and security programmes. ${ }^{104}$ The military became extensively invested directly and indirectly - in new businesses, including hotels, resorts and farms. ${ }^{105}$ As is typical in contested territories, archaeologists were also at the service of the state, 'rediscovering' ancient sites, including those with Buddhist symbolism, and thereby denying any historical basis for a separate territorial status for the north. Buddhist activists sought to impose their own symbolism of dominance, including the erection of Buddhist statues and other religio-nationalist symbols. ${ }^{106}$

This unitary spatial imaginary was apparently contradicted by formal decentralisation, in the form of provincial councils - as mandated by the $13^{\text {th }}$ amendment - which began functioning in the Eastern Province in 2008 and in the Northern Province in 2013. As Klem points out, this formal decentralisation immediately introduces spatial and discursive contradictions, in which the Northern Provincial Council operated in ways that were profoundly critical of the sovereign project of the Sri Lankan state. ${ }^{107}$ For nationalists, the 13th amendment, adopted as part of the Indo-Sri Lanka Peace Accord of 29 July 1987, merely reinforced the Sinhala nationalist fear of linkages between Tamil separatist movement and a powerful Indian state. In practice, however, this formal dispersal of formal powers to Provincial Councils did not significantly undermine the evolution of the centralised sovereign space, since the latter was continually reinforced through both military practices and through formal and informal economic controls, while the Northern Council was limited in funding, dependent on the centre, and undermined by political division and the 
profound challenges of post-conflict reconstruction. Consequently, these contested spatial politics can be understood, not as competing binary projects, as during the conflict, but as multi-layered understandings of the state, in which the formal lines of the constitutional state-space are often in tension with the semi-formal and informal state-spaces enacted by economic and military practices and power. ${ }^{108}$ In their detailed study of decentralisation in Eastern Province, Goodhand, Klem and Walton concluded that 'far from being a technical solution to the "ethnic problem" ... local government has been a lightning rod for local, national and international interests and insecurities and as a result has added new layers of complexity to a protracted conflict'. ${ }^{109}$

Many Tamils in the north interpreted this military-dominated process of post-conflict economic development and infrastructurebuilding as an extension of long-standing state projects that involve resettlement, economic development and colonisation. Yet these totalising visions of space are always contested. Continued military occupation of land provoked mass protests in the Northern Province. On several occasions, local people prevented military survey teams from operating, fearing further land appropriations. ${ }^{110}$ Using the work of James Scott, Perera argues that even during the conflict, everyday 'infrapolitics' produced spaces that were more diverse and more hybrid than the totalizing rhetorical mapping of political elites might suggest. Instead of clear boundaries and homogeneous spaces, everyday politics produces 'messy spaces', resistant to elite visions and the naturalisation of a binary division of territory. Even less powerful social actors can shape spatial structures, resulting in 'contested spaces within and outside of these landscapes that are lived, performed and (re)produced anew by people on the ground'. ${ }^{111}$ Since the war's end, Klem notes two processes taking place simultaneously. First, territorialisation - 'the spatial consolidation of the government's military victory over the LTTE', which includes 'the creation of demarcated zones for economic and military purposes, strategic road construction, the refurbishment of 'sacred sites' and contentious changes in the ethnic demography'. At the same time, however, 'circulation' undermines some aspects of this territorialisation, opening up the region to 'external influences, ranging from evangelical churches and Buddhist pilgrims to (drunken) tourists, and massage parlours'. 112

The complexity of post-conflict order lies in this ongoing contestation, through the multiple initiatives of business, politics and trade, state and international initiatives, and through the return, resettlement and movement of individuals and communities. In this pluralistic society, hegemonic control of space is always countered at all levels of society, producing unexpected and sometimes new forms of inclusive and hybrid space. At other times, however, space is commandeered and shaped by powerful economic and political forces that displace difference and hybridity. In an account of the architecture of post-war Colombo, Jonathan Spencer gazes on a 'grandiose neoclassical school for the Defence College', where many of the floors 
seem empty and lifeless. Spencer contrasts a 'vision of empty and pointless order...enclosed behind a thick wall' with the 'boisterously diverse neighbourhood' that once occupied the space. ${ }^{113}$

\section{Conclusion}

In January 2015 Mahinda Rajapaksa unexpectedly lost the presidential election to former Health Minister, Maithripala Sirisena, who had campaigned on a campaign of good governance and reconciliation, promising 'no more abductions, no more censorship'. ${ }^{114}$ The regime was successfully challenged by civil society activism, by the everyday contestation of space by people in the north and east, and by coalitions of voters that undermined the lines of division and enmity that his administration had promoted. Sri Lankan society seemed too complex to be subordinated to simple binary divisions and too war-weary to tolerate an administration willing to operate outside the rule of law in a succession of exceptional cases. However, the new coalition government quickly ran into problems. Popular support for the Rajapaksas revived in opposition in response to government infighting and a failure to deliver on policy promises. Discontent with the government was only compounded by the failure to prevent mass terrorist attacks by Islamist militants in 2019. Although Mahinda Rajapaksa was barred from running for a further term in office, his brother Gotabaya Rajapaksa capitalised on the unpopularity of the government and won presidential elections in November 2019.

The return of the Rajapaksa family to power was the consequence of many local political factors, but it also reflected one of Schmitt's most important insights - the recognition that politics is also an affective practice in which political leaders can win popular support through the active articulation of a politics of identity. Schmitt's conceptualisation of democracy as 'an identity of governed and governing' relied on a moment of psychological identification between a leader and society, an emotional bond often absent from liberal and technocratic political programmes. In this identitarian turn, Sri Lanka's post-war politics overlapped with a much wider global political trend that challenged all the fundamental tenets of post-Cold War liberalism. Sri Lanka's illiberal peace should be considered in the context of an anti-liberal ideological wave that included the rise of the populist right in Europe, the anti-liberal authoritarianism of Putinism, the resurgence of American nativism, the politics of Hindutva in India, and the search for authoritarian solutions to conflicts in Chechnya, Syria, Myanmar and elsewhere. ${ }^{115}$ It is within this wider global politics of anti-liberalism - most deeply theorised by Carl Schmitt - that the turn to illiberal peace-building can be better understood. Schmitt undoubtedly provides a powerful critique of liberal order that has considerable resonance in critiques of technocratic liberalism and liberal peace-building. Yet the clear lesson of Schmitt's own troubled intellectual journey is that political order achieved through a culture of exceptionality, a discourse of friend and enemy, and an authoritarian 
spatial politics ultimately only deepens political and social divides and risks fuelling further conflict.

Notes

${ }^{1}$ Lewis, 'The Failure'; Goodhand, Korf and Spencer, Conflict and Peace-building; Piccolino, 'Winning Wars'; Russell, 'Ramzan

Kadyrov's "Illiberal Peace"'; Smith, 'Illiberal Peace-building'; Lewis et al., 'Illiberal Peace?'.

${ }^{2}$ See Introduction to this Special Issue, and Lewis et al., 'Illiberal

Peace?'.

${ }^{3}$ Sørbø et al. Pawns of Peace.

${ }^{4}$ ICG, War Crimes; ICG, Reconciliation in Sri Lanka; Goodhand, 'Stabilising a Victor's Peace?; Höglund and Orjuela, 'Winning the Peace; Höglund and Orjuela, 'Hybrid Peace Governance'; Lewis, 'Counterinsurgency in Sri Lanka'; Weiss, The Cage.

${ }^{5}$ Jarstad and Sisk, From War to Democracy; Paris, At War's End; Toft, Securing the Peace; Zürcher et al. Costly Democracy.

${ }^{6}$ Paris, At War's End.

${ }^{7}$ Kovacs and Svensson, 'The Return of Victories?'.

${ }^{8}$ Cooley, 'Countering Democratic Norms'; Wolff and Zimmermann, 'Between Banyans and Battle Scenes'.

${ }^{9}$ Stuenkel, 'The BRICS'; Rotmann et al. 'Major Powers'.

${ }^{10}$ Paris, At War's End.

${ }^{11}$ Lewis, 'The Myopic Foucauldian Gaze'

${ }^{12}$ Soares de Oliveira, 'Illiberal Peace-building in Angola'; Piccolino, 'Winning Wars'; Russell, 'Ramzan Kadyrov's "Illiberal Peace", Smith, 'Illiberal Peace-building'; Lewis et al., 'Illiberal Peace?'.

${ }^{13}$ Smith, 'Illiberal Peace-building'.

${ }^{14}$ Lewis et al., 'Illiberal Peace?'

${ }^{15}$ Bluhm and Varga, New Conservatives.

${ }^{16}$ There are several biographical works in English on Carl Schmitt, of which Bendersky, Carl Schmitt remains the most readable and sympathetic, and Mehring, Carl Schmitt, the most comprehensive.

${ }^{17}$ McCormick, Carl Schmitt's Critique; Müller, A Dangerous Mind.

${ }^{18}$ Schmitt, Political Theology, 5.

${ }^{19}$ Schmitt, Concept of the Political, 53.

${ }^{20} \mathrm{Schmitt}$, Concept of the Political, 26.

${ }^{21} \mathrm{Schmitt}$, Concept of the Political, 32.

${ }^{22} \mathrm{Schmitt}$, Concept of the Political, 33.

${ }^{23}$ Legg, Spatiality, Sovereignty and Carl Schmitt; Minca and Rowan, On Schmitt and Space.

${ }^{24}$ Schmitt, Nomos.

${ }^{25}$ Schmitt, 'The Großraum Order', 87.

${ }^{26}$ Schmitt, 'The Großraum Order', 87.

${ }^{27}$ Schmitt, Political Theology, 13.

${ }^{28}$ Schmitt, On the Three Types, 74.

${ }^{29}$ Lewis et al., 'Illiberal Peace?'; Smith, 'Illiberal Peace-building'. 
${ }^{30}$ Glasius, 'What Authoritarianism Is'; Koch, 'Orientalizing Authoritarianism.'

${ }^{31}$ Schmitt, Political Theology, 13.

${ }^{32}$ ICG, Sri Lanka's Authoritarian Turn.

33 Jayewardene and other previous presidents had also attempted to revive this monarchical lineage in an attempt to legitimise their aspirations for extensive presidential powers.

${ }^{34}$ Coomaraswamy and de los Reyes, 'Rule by Emergency'; Satkunanathan, 'The Executive and the Shadow State'.

${ }^{35}$ Coomaraswamy and de los Reyes, 'Rule by Emergency', 283.

${ }^{36}$ Schmitt, On Dictatorship.

${ }^{37}$ UN Secretary General, Report of the Secretary-General's Panel of Experts, 17.

${ }^{38}$ ICG, War Crimes; University Teachers for Human Rights, 'Slow Strangulation of Jaffna'; HRW, Recurring Nightmare; UN, Report of the OHCHR Investigation.

${ }^{39}$ Agamben, State of Exception, 32-35; Head, Emergency Powers; Hagmann \& Korf, 'Agamben in the Ogaden', 210; Keen, "The Camp".

${ }^{40}$ Agamben, State of Exception, 51, 40.

${ }^{41}$ Schmitt, Political Theology: 12.

${ }^{42}$ ICG, War Crimes; UN Secretary General, Report of the SecretaryGeneral's Panel of Experts, 23-30.

${ }^{43}$ ICG, War Crimes, 14.

${ }^{44}$ UN Secretary General, Report of the Secretary-General's Panel of Experts, 17.

${ }^{45}$ Lewis et al., 'Illiberal Peace?'; Lewis and Sagnayeva, 'Corruption, Patronage and Illiberal Peace'.

${ }^{46}$ HRW, Funding the "Final War", 1-2.

${ }^{47}$ UTHR(J), "In the Name of 'Peace".

${ }^{48}$ DeVotta, 'Sri Lanka: From Turmoil to Dynasty', 142; US

Department of State, 'Sri Lanka'.

${ }^{49}$ Roberts, 'The Superficiality of Statebuilding'; Soares de Oliveira, 'Illiberal Peace-building in Angola'; Zabyelina, 'Buying Peace'.

${ }^{50}$ Cheng and Zaum, Corruption; Lewis \& Sagnayeva, 'Corruption, Patronage and Illiberal Peace'; Lewis et al, 'Illiberal Peace?'; Zabyelina and Arsovska, 'Rediscovering Corruption's Other Side'.

${ }^{51}$ Maria Abi-Habib, 'How China Got Sri Lanka'.

${ }^{52}$ Reuters, 'Sri Lanka Court'.

${ }^{53}$ Al-Jazeerah, 'Sri Lankan President Gotabaya Rajapaksa Swears in Brother'.

${ }^{54}$ Schmitt, Concept of the Political, 19.

${ }^{55}$ Ibid, 45.

${ }^{56}$ Rajapaksa, 'Address by Pres. Rajapaksa to Los Angeles World Affairs Council'.

${ }^{57}$ Fearon and Laitin, 'Ethnicity, Insurgency, and Civil War'; Collier et al. 'Beyond Greed and Grievance'. See Keen, 'Greed and grievance', for a critique.

${ }^{58}$ Spencer, Anthropology; Spencer, 'A Nationalism without Politics'.

${ }^{59}$ Spencer, Anthropology, 180. 
${ }^{60}$ Venugopal, 'The Making of Sri Lanka's Post-Conflict Economic Package'.

${ }^{61}$ Ismail, Abiding by Sri Lanka; see also Stepan, 'India, Sri Lanka, and the Majoritarian Danger'.

${ }^{62}$ Ismail, Abiding by Sri Lanka, 34.

${ }^{63}$ Schmitt, The Crisis of Parliamentary Democracy, 14.

${ }^{64} \mathrm{Schmitt}$, The Crisis of Parliamentary Democracy, 9.

${ }^{65}$ Mouffe, The Challenge, 41.

${ }^{66}$ Rajapaksa, 'President Rajapaksa's Speech to Parliament'.

${ }^{67}$ Wallace, 'Confronting Wrongs, Affirming Difference', 202-203.

${ }^{68}$ Moore, 'The Ideological History', 190.

${ }^{69}$ Rajapaksa, 'President Rajapaksa's Speech to Parliament'.

${ }^{70}$ De Silva, A History of Sri Lanka, 21.

${ }^{71}$ DeVotta, 'Sri Lanka: From Turmoil to Dynasty', 130.

${ }^{72}$ ODI, Humanitarian Space, 3; Keen, “"The Camp”, 11.

${ }^{73}$ Walton, 'Conflict, Peace-building and NGO Legitimacy'.

${ }^{74}$ Seoighe, War, Denial and Nation-Building, 22.

${ }^{75}$ Peterson, 'Creating Space'.

${ }^{76}$ Peterson, 'Creating Space', 325.

${ }^{77}$ ICG, Sri Lanka: The Failure; Lewis, 'Sri Lanka'.

${ }^{78}$ Schmitt, The Leviathan, 74.

${ }^{79}$ Jurkevics, 'Arendt reads Carl Schmitt', 350.

${ }^{80}$ Spencer, 'Performing Democracy', 729.

${ }^{81}$ ICG, Sri Lanka's Potemkin Peace, ii.

${ }^{82}$ Ramachandran, 'Sri Lanka's Anti-Muslim Violence'.

${ }^{83}$ Klem, 'The Problem of Peace'.

${ }^{84}$ Al Maeena, 'Neo-Fascism on the Rise'.

${ }^{85}$ There is, of course, an alternative perspective on liberal

international order, which emphasises its assertion of state spaces and its securitization of state boundaries against transnational mobility, including the physical movement of refugees. For an argument that the essentially state-centric model of international relations that underpins the liberal international order made the failure of peace in Sri Lanka inevitable, see Rampton and Nadarajah, 'A Long View'. See also Nadarajah, 'The Tamil Proscriptions', for a wide-ranging critique of 'global liberal order-making' and its impact on the Sri Lankan conflict.

${ }^{86}$ Galli, 'Carl Schmitt and the Golden Age', 20.

${ }^{87}$ Rampton, 'A Game of Mirrors'.

${ }^{88}$ Wijeyeratne, 'Galactic Polities', 222.

${ }^{89}$ Rampton, 'A Game of Mirrors', 375.

${ }^{90}$ Wijeyeratne, 'Galactic Polities', 217.

${ }^{91}$ Schmitt, Nomos, 42.

${ }^{92}$ Schmitt, Concept of the Political, 92.

${ }^{93}$ Moore, 'The Ideological History', 180.

${ }^{94}$ Rampton, 'A Game of Mirrors', 379

${ }^{95}$ Ibid., 378

${ }^{96}$ Ibid., 379.

${ }^{97}$ Wilson, Sri Lankan Tamil Nationalism.

${ }^{98}$ Mampilly, Rebel Rulers; Staniland, Networks of Rebellion. 
${ }^{99}$ Brenner, 'Authority in Rebel Groups', 409.

${ }^{100}$ Terpstra \& Frerks, 'Rebel Governance and Legitimacy'.

${ }^{101}$ Hansen and Stepputat, States of Imagination.

${ }^{102}$ DeVotta, 'Sri Lanka: From Turmoil to Dynasty', 141.

${ }^{103}$ Pieris, 'Arterial Blockages', 210.

${ }^{104}$ Seoighe, War, Denial and Nation-Building, 158; Satkunathan, 'The Executive and the Shadow State'; Spencer, 'Securitization and its Discontents'.

${ }^{105}$ According to an ICG report, "There are no public, trusted figures for how much land, public or private, the military holds and no transparency regarding often contradictory government claims". ICG calls for 'a government baseline study of such land, preferably with the northern and eastern provincial councils and the UN or another international body', an initiative which they claim 'would build trust and capacity'. ICG, Sri Lanka's Transition, 18, fn 69.

${ }^{106}$ ICG, Sri Lanka's Transition, 18; Seoighe, 'Inscribing the Victor's Land'; Seoighe, War, Denial and Nation-Building, 168.

${ }^{107}$ Klem, 'The Problem of Peace', 245.

${ }^{108}$ On the concept of the multi-layered state space, see Lewis, 'The Contested State'.

${ }^{109}$ Goodhand et al., 'Mediating the Margins', 818.

${ }^{110}$ Seoighe, War, Denial and Nation-Building, 165.

${ }^{111}$ Perera, 'Rebuilding Lives', 190.

112 Klem, 'The Political Geography of War's End', 44.

113 Spencer, 'Securitization', 107.

${ }^{114}$ Burke and Perera, 'Sri Lanka's New President'.

${ }^{115}$ For a more detailed account, see Lewis, Russia's New Authoritarianism. 
References

Abi-Habib, Maria, 'How China Got Sri Lanka to Cough Up a Port'. New York Times, 25 June 2018. Available at: https://www.nytimes.com/2018/06/25/world/asia/chinasri-lanka-port.html [Accessed 27 November 2019].

Al-Jazeera, 'Sri Lankan President Gotabaya Rajapaksa Swears in Brother as PM', Al-Jazeera, 21 November 2019. Available at: https://www.aljazeera.com/news/2019/11/sri-lankanpresident-gotabaya-rajapaksa-swears-brother-pm191121093052727.html [Accessed 27 November 2019].

Al Maeena, Tariq A. 'Neo-Fascism on the Rise in Sri Lanka', Gulf News, 23 February 2013. Available at: https://gulfnews.com/opinion/thinkers/neo-fascism-onthe-rise-in-sri-lanka-1.1150052 [Accessed 27 November 2019]

Agamben, Giorgo, 2005. State of Exception. Trans. K. Attell. University of Chicago Press, Chicago.

Bendersky, Joseph J., 1983. Carl Schmitt: Theorist for the Reich. Princeton University Press, Princeton, NJ.

Bluhm, Katharina and Mihai Varga (eds), 2019. New Conservatives in Russia and East Central Europe. Routledge, London.

Brenner, David, 2017. 'Authority in Rebel Groups: Identity, Recognition and the Struggle over Legitimacy'. Contemporary Politics 23(4), 408-426.

Burke, J. and A. Perera, 'Sri Lanka's New President Promises "No More Abductions, No More Censorship"'. The Guardian, 10 January 2015. Available at: https://www.theguardian.com/world/2015/jan/10/srilanka-president-maithripala-sirisena-promise-change [Accessed 20 December 2019].

Cheng, Christine and Dominik Zaum (eds.), 2012. Corruption and Post-conflict Peace-building: Selling the Peace? Routledge, London.

Collier, Paul, Anke Hoeffler and Dominic Rohner, 2009. 'Beyond Greed and Grievance: Feasibility and Civil War'. Oxford Economic Papers 61, 1-27.

Cooley, Alexander, 2015. 'Countering Democratic Norms'. Journal of Democracy 26(3): 49-63.

Coomaraswamy, Radhika and Charmaine de los Reyes, 2004. 'Rule by Emergency: Sri Lanka's Postcolonial Constitutional Experience'. International Journal of Constitutional Law 2(2), 272-295

De Silva, K. M., 1981. A History of Sri Lanka. London: Hurst.

DeVotta, Neil, 2011. 'Sri Lanka: From Turmoil to Dynasty'. Journal of Democracy 22(2), 130-144.

Fearon, James D. and David D. Laitin, 2003. 'Ethnicity, 
Insurgency, and Civil War'. The American Political Science Review 97(1), 75-90

Galli, Carlo and Elisabeth Fay, 2010. 'Carl Schmitt and the Golden Age'. The New Centennial Review 10(2), 1-26.

Glasius, Marlies, 2018. 'What Authoritarianism Is... and Is Not: A Practice Perspective'. International Affairs 94(3), 515533.

Goodhand, Jonathan, 2010. 'Stabilising a Victor's Peace? Humanitarian Action and Reconstruction in Eastern Sri Lanka'. Disasters 34(3), 342-367.

Goodhand, Jonathan, Bart Klem and Oliver Walton, 2016. 'Mediating the Margins: The Role of Brokers and the Eastern Provincial Council in Sri Lanka's Post-war Transition'. Third World Thematics: A TWQ Journal 1(6), 817-836.

Hagmann, Tobias, and Benedict Korf, 2012. 'Agamben in the Ogaden: Violence and Sovereignty in the EthiopianSomali Frontier'. Political Geography 31(4): 205-214.

Hansen, Thomas B. and Finn Stepputat, 2001. States of Imagination: Ethnographic Explorations of the Postcolonial State. Duke University Press.

Head, Michael, 2017. Emergency Powers in Theory and Practice: The Long Shadow of Carl Schmitt. Routledge, London

Höglund, Kristine, and Camilla Orjuela, 2011. 'Winning the Peace: Conflict Prevention after a Victor's Peace in Sri Lanka'. Contemporary Social Science 6(1), 19-37.

Höglund, Kristine and Camilla Orjuela, 2012. 'Hybrid Peace Governance and Illiberal Peacemaking in Sri Lanka'. Global Governance 18, 89-104.

Hoole, Rajan, Daya Somasundaram, K. Sritharan and Rajani Thiranagama, 1990. The Broken Palmyra: The Tamil Crisis in Sri Lanka - An Inside Account. Sri Lanka Studies Institute, Claremont, CA.

HRW, 2006. Funding the "Final War" LTTE Intimidation and Extortion in the Tamil Diaspora. Human Rights Watch, 14 March.

HRW, 2008. Recurring Nightmare: State Responsibility for "Disappearances" and Abductions in Sri Lanka. Human Rights Watch, 5 March.

ICG, 2006. Sri Lanka: The Failure of the Peace Process. International Crisis Group, Asia Report 124, 28 November.

ICG, 2010. War Crimes in Sri Lanka. International Crisis Group, Asia Report 191, 17 May.

ICG, 2011. Reconciliation in Sri Lanka: Harder than Ever. International Crisis Group, Asia Report 209, 18 July.

ICG, 2013. Sri Lanka's Authoritarian Turn: The Need for International Action. International Crisis Group, Asia Report 243, 20 February. 
ICG, 2013. Sri Lanka's Potemkin Peace: Democracy under Fire. International Crisis Group, Asia Report No. 253, 13 November.

ICG, 2017. Sri Lanka's Transition to Nowhere. International Crisis Group, Asia Report 286, 16 May.

Ismail, Qadri, 2005. Abiding by Sri Lanka: On Peace, Place, and Postcoloniality. University of Minnesota Press, Minneapolis.

Jarstad, Anna K. and Timothy D. Sisk (eds.), 2008. From War to Democracy: Dilemmas of Peace-building. Cambridge University Press, Cambridge.

Jurkevics, Anna, 2017. 'Hannah Arendt reads Carl Schmitt's The Nomos of the Earth: a dialogue on law and geopolitics from the margins'. European Journal of Political Theory 16(13), 345-366.

Keen, David, 2012. 'Greed and Grievance in Civil War'. International Affairs 88, 757-777.

Keen, David, 2014. "The Camp" and "the Lesser Evil": Humanitarianism in Sri Lanka'. Conflict, Security \& Development 14(1), 1-31.

Klem, Bart, 2014. 'The Political Geography of War's End: Territorialisation, Circulation, and Moral Anxiety in Trincomalee, Sri Lanka'. Political Geography 38, 33-45.

Klem, Bart, 2018. 'The Problem of Peace and the Meaning of 'Post-War'. Conflict, Security \& Development 18(3), 233-255.

Koch, Natalie, 2017. 'Orientalizing Authoritarianism: Narrating US Exceptionalism in Popular Reactions to the Trump Election and Presidency'. Political Geography 58, 145147.

Kovacs, Mimi Soderbergh, and Isak Svensson, 2013. 'The Return of Victories?: The Growing Trend of Militancy in Ending Armed Conflicts'. Paper prepared for the 7th general conference of the European Consortium for Political Research (ECPR), Sciences Po Bordeaux, Domaine Universitaire, Bordeaux, 4-7 September.

Legg, Stephen (ed.), 2011. Spatiality, Sovereignty and Carl Schmitt: Geographies of the Nomos. Routledge, London.

Lewis, David, 2010. 'The Failure of a Liberal Peace: Sri Lanka's Counter-insurgency in Global Perspective'. Conflict, Security \& Development 10(5), 647-671.

Lewis, David, 2012. 'Counterinsurgency in Sri Lanka: A Successful Model?'. In The Routledge Handbook of Insurgency and Counterinsurgency, ed. Paul B. Rich and Isabelle Duyvesteyn. Routledge, London, 319-330.

Lewis, David, 2017. 'The Myopic Foucauldian Gaze: Discourse, Knowledge and the Authoritarian Peace.' Journal of Statebuilding and Intervention 11(1), 21-41.

Lewis, David, 2017. 'The Contested State in Post-Soviet Armenia'. In The Logic of Weak States, ed. John 
Heathershaw and Ed Schatz. Pittsburgh University Press, Pittsburgh, 120-135.

Lewis, David G., 2019. 'Sri Lanka'. In Comparing Peace Processes, ed. R. Mac Ginty and A. Ozerdem. Routledge, London, 285-302.

Lewis, David G., 2020. Russia's New Authoritarianism: Putin and the Politics of Order. Edinburgh University Press, Edinburgh.

Lewis, David G., John Heathershaw, and Nick Megoran, 2018. 'Illiberal Peace? Authoritarian Modes of Conflict Management'. Cooperation and Conflict 53(4), 486-506.

Mampilly, Zachariah C., 2011. Rebel Rulers: Insurgent Governance and Civilian Life during War. Cornell University Press, Ithaca, NY.

McCormick, John P. 1997. Carl Schmitt's Critique of Liberalism: Against Politics as Technology. Cambridge University Press, Cambridge.

Mehring, Reinhard, 2014. Carl Schmitt: A Biography. Polity, Cambridge.

Minca, Claudio and Rory Rowan, 2015. On Schmitt and Space. Routledge, London.

Moore, Mick, 1989. 'The Ideological History of the Sri Lankan Peasantry'. Modern Asian Studies 23, 179-207.

Mouffe, Chantal, 1999. The Challenge of Carl Schmitt. Verso, London.

Müller, Jan-Werner, 2003. A Dangerous Mind: Carl Schmitt in Post-war European Thought. Yale University Press, New Haven, CT.

Nadarajah, Suthaharan, 2018. 'The Tamil Proscriptions: Identities, Legitimacies, and Situated Practices'. Terrorism and Political Violence 30(2), 278-297.

ODI, 2010. Humanitarian Space in Sri Lanka: What Lessons can be Learned? ODI (HPG), Summary of Meeting, 18-19 November, Overseas Development Institute, London.

Paris, Roland, 2004. At War's End: Building Peace after Civil Conflict. Cambridge University Press, Cambridge.

Paris, Roland, 2010. 'Saving Liberal Peace-building'. Review of International Studies 36, 337-365.

Perera, Nihal, 2009. 'Rebuilding Lives, Undermining Oppositions: Spaces of War and Peace in the North'. In Spatialising Politics: Culture and Geography in PostColonial Sri Lanka, ed. Catherine Brun and Tariq Jazeel. Sage, New Delhi, 168-193.

Peterson, Jenny H., 2013. 'Creating Space for Emancipatory Human Security: Liberal Obstructions and the Potential of Agonism'. International Studies Quarterly 57(2), 318328.

Piccolino, Giulia, 2015. 'Winning Wars, Building (Illiberal) Peace? The Rise (and Possible Fall) of a Victor's Peace in Rwanda and Sri Lanka'. Third World Quarterly 36(9), 
1770-1785.

Pieris, Anoma, 2015. 'Arterial Blockages: The Catastrophic Itineraries of the Sri Lankan Civil War.' National Identities 17(2), 195-215.

Rampton, David, 2012. 'A Game of Mirrors: Constitutionalism and Exceptionalism in a Context of Nationalist Hegemony'. In The Sri Lanka Republic at 40: Reflections on Constitutional History, Theory, and Practice, ed. Asanga Welikala. Centre for Policy Alternatives, Colombo, 365-40.

Rampton, David and Suthaharan Nadarajah, 2017. 'A Long View of Liberal Peace and its Crisis', European Journal of International Relations 23(2): 441-465.

Rajapaksa, Mahinda, 2007. Address by Pres. Rajapaksa to the Los Angeles World Affairs Council, 28 September. Available at: http://www.president.gov.lk/speech_New.asp?Id=38 [Accessed 16 November 2019.]

Rajapaksa, Mahinda, 2009. 'President Rajapaksa's Speech to Parliament on the Defeat of the LTTE, 19 May 2009. Available at: http://www.island.lk/2009/05/20/features4.html [Accessed 26 November 2019].

Reuters, 'Sri Lanka Court Jails Top Former Senior Officials for Graft', Reuters, 7 September 2017

Roberts, David, 2009. 'The Superficiality of Statebuilding in Cambodia: Patronage and Clientilism as Enduring Forms of Politics'. In The Dilemmas of Statebuilding, ed. Roland Paris and Timothy D. Sisk. Routledge, London, 149-170.

Rotmann, Philipp, Gerrit Kurtz, and Sarah Brockmeier, 2014. 'Major Powers and the Contested Evolution of a Responsibility to Protect'. Conflict, Security and Development 14(4), 355-377.

Russell, John, 2014. 'Ramzan Kadyrov's "Illiberal Peace" in Chechnya'. In Chechnya at War and Beyond, ed. A. Le Huérou, A. Merlin, A. Regamey and E. Sieca-Kozlowsk. Routledge, London, 133-151.

Satkunanathan, Ambika, 2015. 'The Executive and the Shadow State in Sri Lanka'. In Reforming Sri Lankan Presidentialism: Provenance, Problems and Prospects, ed. Asanga Welikala. Centre for Policy Alternatives, Colombo.

Schmitt, Carl, 1985. Political Theology: Four Chapters on the Concept of Sovereignty. Trans. George Schwab. MIT Press, Cambridge, MA.

Schmitt, Carl, 1985. The Crisis of Parliamentary Democracy. Trans. Ellen Kennedy. MIT Press, Cambridge, MA.

Schmitt, Carl, 2003. The Nomos of the Earth in the International Law of Jus Publicum Europeaum. Trans. G. L. Ulmen. 
Telos Press, New York.

Schmitt, Carl, 2004. On the Three Types of Juristic Thought. Trans. Joseph Bendersky. Praeger, Westport, CT.

Schmitt, Carl, 2007. Concept of the Political. University of Chicago Press, Chicago.

Schmitt, Carl, 2008. The Leviathan in the State Theory of Thomas Hobbes. Trans. G. Schwab and E. Hilfstein. University of Chicago Press, Chicago.

Schmitt, Carl, 2011. 'The Großraum Order of International Law with a Ban on Intervention for Spatially Foreign Powers: A Contribution to the Concept of Reich in International Law (1939-1941'). In Carl Schmitt, Writings on War. Trans. and ed. T. Nunan. Polity, Cambridge, 75-124.

Schmitt, Carl, 2014. On Dictatorship. From the Origin of the Modern Concept of Sovereignty to Proletarian Class Struggle. Trans. M. Hoelzl and G. Ward. Polity, Cambridge.

Seoighe, Rachel, 2016. 'Inscribing the Victor's Land: Nationalistic Authorship in Sri Lanka's Post-war Northeast'. Conflict, Security and Development 16(5), 443-471.

Seoighe, Rachel, 2017. War, Denial and Nation-Building in Sri Lanka. Palgrave, London.

Smith, Claire, 2014. 'Illiberal Peace-building in Hybrid Political Orders: Managing Violence During Indonesia's Contested Political Transition.' Third World Quarterly 35(8), 1509-1528.

Soares de Oliveira, R., 2011. 'Illiberal Peace-building in Angola.' The Journal of Modern African Studies 49, 287314.

Sørbø, Gunnar, Jonathan Goodhand, Bart Klem, Ada Elisabeth Nissen, and Hilde Selbervik, 2011. Pawns of Peace Evaluation of Norwegian Peace Efforts in Sri Lanka, 1997-2009. Norwegian Agency for Development Cooperation, Oslo.

Spencer, Jonathan, 2007. Anthropology, Politics, and the State: Democracy and Violence in South Asia. Cambridge University Press, Cambridge.

Spencer, Jonathan, 2008. 'A Nationalism Without Politics? The Illiberal Consequences of Liberal Institutions in Sri Lanka'. Third World Quarterly 29(3), 611-629.

Spencer, Jonathan, 2012. 'Performing Democracy and Violence, Agonism and Community, Politics and Not Politics in Sri Lanka'. Geoforum 43(4), 725-731.

Spencer, Jonathan, 2016. 'Securitization and its Discontents: The End of Sri Lanka's Long Post-war?'. Contemporary South Asia 24(1), 94-108.

Staniland, Paul, 2014. Networks of Rebellion: Explaining Insurgent Cohesion and Collapse. Cornell University Press, Ithaca, NY. 
Stepan, Alfred, 2015. 'India, Sri Lanka, and the Majoritarian Danger'. Journal of Democracy 26(1), 128-140.

Stuenkel, Oliver, 2014. 'The BRICS and the Future of R2P'. Global Responsibility to Protect 6(1), 3-28.

Terpstra, Niels, and Georg Frerks, 2017. 'Rebel Governance and Legitimacy: Understanding the Impact of Rebel Legitimation on Civilian Compliance with the LTTE Rule.' Civil Wars 19(3), 279-307.

Toft, Monica Duffy, 2010. Securing the Peace: The Durable Settlement of Civil Wars. Princeton University Press.

UN Secretary General, 2011. 'Report of the Secretary-General's Panel of Experts on Accountability in Sri Lanka'. 31 March. United Nations, New York.

UN, 2015. 'Report of the OHCHR Investigation on Sri Lanka (OISL)'. Human Rights Council, 16 September. Available at: https://www.ohchr.org/en/hrbodies/hrc/pages/oisl.aspx [Accessed 16 November 2019].

UTHR(J), 2002. "In the Name of 'Peace": Terror Stalks the North-East.' University Teachers for Human Rights (Jaffna). Information Bulletin No. 28, 1 February. Available at: http://www.uthr.org/bulletins/bul28.htm [Accessed 16 November 2019].

UTHR(J), 2007. 'Slow Strangulation of Jaffna.' Special Report No. 28, 4 December. University Teachers for Human Rights (Jaffna). Available at: www.uthr.org/SpecialReports/spreport28.htm [Accessed 16 November 2019].

US Department of State, 2007. 'Sri Lanka: GSL Complicity in Paramilitary Factions' Human Rights Abuses'. Cable released by Wikileaks, 18 May.

Venugopal, Rajesh, 2009. 'The Making of Sri Lanka's PostConflict Economic Package and the Failure of the 20012004 Peace Process'. CRISE Working Paper 64. Oxford University, Oxford.

Wallace, Mary, 2010. 'Confronting Wrongs, Affirming Difference: The Limits of Violence, the Power of Nonviolence, and the Case of Nonviolent Intervention in Sri Lanka'. PhD dissertation, Brown University.

Walton, Oliver, 2008. 'Conflict, Peace-building and NGO Legitimacy: National NGOs in Sri Lanka'. Conflict, Security and Development 8, 133-167.

Weiss, Gordon, 2011. The Cage: The Fight for Sri Lanka and the Last Days of the Tamil Tigers. Random House, London.

Wijeyeratne, Roshan de Silva (2003). 'Galactic Polities and the Decentralisation of Administration in Sri Lanka.' Griffith Law Review, 12(2), 215-237.

Wilson, Alfred J., 2000. Sri Lankan Tamil Nationalism. UBC Press, Vancouver. 
Wolff, Jonas and Lisbeth Zimmermann, 2016. 'Between Banyans and Battle Scenes: Liberal Norms, Contestation, and the Limits of Critique. Review of International Studies 42(3): 513-534.

Zabyelina, Yuliya G., 2013. "“Buying Peace” in Chechnya: Challenges of Post-conflict Reconstruction in the Public Sector'. Journal of Peacebuilding \& Development 8(3): $37-49$.

Zabyelina, Yuliya G., and Jana Arsovska, 2013. 'Rediscovering Corruption's Other Side: Bribing for Peace in PostConflict Kosovo and Chechnya.' Crime, Law and Social Change 60(1), 1-24.

Zürcher, Christoph, Carrie Manning, Kristie D. Evenson, Rachel Hayman, Sarah Riese, Nora Roehner (eds.), 2013. Costly Democracy: Peacebuilding and Democratization after War. Stanford University Press, Redwood City, CA. 